\title{
MAPPING EVOLVING HISTORICAL LANDSCAPE SYSTEMS
}

\author{
P. Branduini ${ }^{1}$, R. Laviscio ${ }^{1}$, A. L’Erario ${ }^{2}$, F.C. Toso ${ }^{1}$ \\ ${ }^{1}$ PaRID - Research and International Documentation for Landscape, Dept. Architecture, Built environment and Construction \\ engineering (DABC), Politecnico di Milano, Italy - (paola.branduini, raffaella.laviscio, francescocarlo.toso)@ polimi.it \\ ${ }^{2} \mathrm{PhD}$ student in Preservation of the Architectural Heritage, Dept. of Architecture and Urban Studies (DAStU), Politecnico di Milano, \\ Italy - andrea.lerario@polimi.it
}

KEY WORDS: Landscape, Map, Landscape system, Data collecting, Landscape representation, Historical archives, Public participation, Ecomuseums

\begin{abstract}
:
Landscape is not a sum of elements to be juxtaposed in a paper or a digital space. It is a complex system of relationships among components that have evolved over time. It is not a sum of material permanencies, more or less recognizable and placeable in space, but an interweaving of economic, social, religious and political meanings that link permanencies and give them value.

How to represent these relationships from existing geographic or historical databases? How can we illustrate the co-evolution between nature and culture that has given form to today's landscape? And how to allow at the same time to update data and their relationships?

Through the comparison among examples taken from local participative experiences (ecomuseum community maps) and others directly managed and produced by the Authors (itinerary maps), the contribution reflects on these main critical issues: landscape representation problems, data collecting and updating, information sharing. The main results show that the data digitalization and georeferencing can help to illustrate and understand tangible and intangible characteristics of landscape and overcome the gaps from a sharing mapping procedure with a bottom-up approach and the point of view by the experts with a top-down approach. On the contrary, the digital representation of landscape data shows another set of problems that currently are mainly solved in traditional ways. The paper will also deal with these aspects.
\end{abstract}

\section{INTRODUCTION}

The landscape is a complex system, in which natural elements and anthropic factors - that coexist in a dynamic balance - are read and interpreted by the populations. It is a physical object and, at the same time, it represents people social and sensory perception (European Landscape Convention, Council of Europe, 2000).

It is a palimpsest of tangible and intangible documents regarding the history of nature and people, who built and modified it in response to natural factors and economic and social needs (Antrop, 2005). It is the result of the work of a whole community, and not of single individuals. It is the result of the continuous use of techniques handed down through generations, and not of a rigidly planned design.

The geographical space and the environment that the landscape embraces bear the material traces of historical processes of transformation and settlement, cultural and artistic expressions, the evolution of production techniques and lifestyles (Berque, 1995; Turri, 1998; Antrop, 2012; Luginbuhl, 2012). Artifacts, works, the spatial organization are the tangible outcomes; attributions of meaning, customs and traditions are the intangible ones.

Therefore, the landscape is a complex stratigraphy based on continuous process of design, construction, sedimentation, transformation.

Understanding its meanings implies both knowing the components that constitute it and understanding their historical meanings, as well as the visual, spatial, functional and symbolic relationships that bind all the components together (Laviscio, 2008), the intentions that produced it (Langè et al., 2010) and their "functioning", historical and contemporary (Scazzosi, 2018).

The landscape is a "system" and not just the sum of its components, tangible and intangible. The landscape as a system comprehends its social and functional organization. It is not possible to explain the landscape system by reading its components separately.

The landscape complexity often makes its comprehension difficult to the public, even if people themselves have created it and continues to manage it. The non-comprehension of some "landscape layers" by the population leads to their non-reading. Therefore, the need of tools that will assume the cultural task of revealing that system of components, meanings and values attributed and ascribable to the landscapes we live becomes fundamental. In other words, tools that allow the landscape system to be readable to everybody (and not only to the experts or scholars who study it) and to let people appropriate - or reappropriate - the landscape that they live and continue to transform

The "landscape map" is increasingly used as a tool for decoding landscape complexity. It is a tool for knowledge, often with a tourist-recreational function (Branduini et al., 2017).

A landscape map is often issued by cultural institutions such as museums or ecomuseums, with the meaning given them by Drugman: the landscape as an open and dynamic museum system, a "museum-workshop" which is firmly tied to a community and let the community know itself, appropriate its own history, and generate new stories (Drugman, 2010).

In recent years, also thanks to the European network "Mondi locali", the so-called "Community maps" have been issued in many Italian regions and at different territorial scales, as an evolution of the "cognitive maps" by Kevin Lynch since the 60s and developing the participatory practice of "Parish maps" by the Common Ground in the United Kingdom since the 80s.

Nowadays, Community maps are tools used by several ecomuseums to graphically represent the people's landscape identity through a participatory process (Baratti, 2017). 
They are often clear examples of how it is possible to link the tangible and the intangible components of the landscape, and therefore to represent the relationships of the landscape system. Through the comparison between this type of landscape map and some experiences developed by the PaRID Research group (Research and International Documentation for Landscape, ABC Dept., Politecnico di Milano) with the aim to illustrate itineraries for the discovery of rural Cultural Heritage ("AgroCulture Itineraries", MUSA, 2015; "The way of wintermeadows", Ticino Park, 2019), the purpose of this contribution is to reflect on the critical issues related to the representation and communication of a complex system like the landscape. The need for a selection and simplification of data, the difficulty of representing the relationships that bind the landscape components (both tangible and intangible), the issue of collecting and updating data.

The examples are analyzed in relation to some main questions:

1. What are the methods to select the contents?

2. What the criteria used in the representation?

3. What is the system used for data publishing and sharing?

Concluding remarks reflect on the exhaustiveness of the contents, the effectiveness of the representation, the appropriate methods of finding and updating data, the shortcomings and other aspects to be developed.

\section{LANDSCAPE DATA COLLECTING AND REPRESENTATION THROUGH MAPS: SUGGESTIONS FROM THE ITALIAN ECOMUSEUMS}

When discussing about landscape data collecting and representation through maps, a reference to the experiences of Community maps by the Italian ecomuseums is mandatory. Italian ecomuseums are among the most important developers of landscape maps, through an approach that could be called "collective landscape data collecting".

The phenomenon of the Community maps of Italian ecomuseums has an important precursor in the "Parish maps" by several British communities (Madau, 2015), starting from the $80 \mathrm{~s}$ of the 20th century by the Common Ground. The experience of the Common Ground's "Parish Maps project" was born with the aim to help people in working together to identify those landscape elements, tangible or intangible, which are considered of value from a local point of view in order to reinforce local identity and to make them have an active role to «take action and some control in shaping the future of their place» (cfr. Common Ground website). Parish maps were created as «systems of storytelling and visualization of the relationships between people and places» (Clifford, King, 1996). Parish maps are «much more than a simple representation of the territory: [they go] further by communicating, through simple signs, the infinite complexity of the system of relationships that exist between the places and their inhabitants» (Turchi, 2015: 4).

Even if the context in which British "Parish maps" and Italian "Community maps" by ecomuseums were conceived differ, the first practice has influenced the second one.

The last census of Italian ecomuseums ${ }^{1}$, realized within the Politecnico di Milano, shows how effectively the production of Community maps by ecomuseums is relevant (D'Amia, 2017; L'Erario, 2017).

The census revealed a total of 209 ecomuseums of which only 35 produced at least one Community map. Despite the low number of ecomuseums that produced a landscape map (only

${ }^{1}$ The previous censuses of Italian ecomuseums were realized by Maurizio Maggi (IRES Piemonte, 2002) and Raffaella Riva (Politecnico di Milano, 2008). the 17\%), 64 Community maps have been published. Most of the Community maps were developed in Northern Italy ecomuseums, less in Central and Southern Italy (except for the ecomuseums in Salento provinces in Apulia). The number of maps has grown in the last years: in 2006 the Italian Community maps were about ten (Clifford et al., 2006: 67). Therefore, in the last 13 years the number of maps has increased of six-folds.

Through the ecomuseums census and the identification of the Community maps ${ }^{2}$ it is possible to identify recurrent data collecting and representation:

1. The direct involvement of local people through participatory activities for the landscape data collecting, regarding both tangible and intangible heritage (also in relation to the historical memory of the places);

2. The representation on a map of both tangible and intangible landscape heritage to represent the relationships system among the landscape components and the inhabitants' identity, thanks to the use of simple graphic signs, short texts or pictures.

Most of the Community maps are aimed at 'representing' the identity of the local community, as well as the system of relationship among tangible and intangible components of the landscape through the time.

The involvement of local people allowed the creation of Community maps with a bottom-up approach. The detailed description of the design process of some Community maps is sometimes published on the ecomuseums websites ${ }^{3}$.

From these publications it emerges that the design process of Community maps is similar for almost all the ecomuseums experiences: the most common methods used for data collecting through the participation of local people are workshops, field surveys, interviews, questionnaires, or projects in local schools. The presence of facilitators was always required during the management of the design process of a new map, in order to drive people in organizing and collecting their ideas. However, in several cases the participation of people in events was sometimes limited, especially in the early stages.

Occasionally, the data from the citizens have been completed thanks to further historical research carried out by experts in local archives.

On the contrary, the path followed for the synthesis of the collected data and the graphic representation of the maps is often different from an ecomuseum to another. The choice of the best ways of representation of complex data of different nature often brought to difficulties.

In some cases, the decision has been to involve the population only in the data collecting phase, while only experts and facilitators took part in the phase dedicated to the graphic development of the map. In other, the community participated in both the phases.

Most of the Community maps of the Italian ecomuseums were issued on a traditional paper support (61 maps of 64).

However, three innovative digital Community maps have been identified. These three maps were developed by the Ecomuseo delle Acque del Gemonese ("Mappa del fiume Levra") ${ }^{4}$, the

\footnotetext{
2 The identification of Community maps has been done with a systematic search on the web, in particular by consulting the ecomuseums websites. It may be that the real number of Community maps is greater than indicated.

${ }^{3}$ In particular, the Authors refer to the documentation available on the website www.mappadicomunita.it which refers the experience of several ecomuseums.

${ }^{4}$ www.mappadelfiumeledra.it/index.htm
} 
Ecomuseo Urbano Metropolitano Milano Nord $^{5}$ (EUMM) and by the Ecomuseo Milano Sud (MUMI) ${ }^{6}$. Community maps on paper, as well as the digital ones, present strengths and weaknesses.

The maps developed for the paper support, despite being printed on a static support that does not allow modifications, show a greater flexibility in the representation modalities. Furthermore, this limitation often constitutes a strong point as it obliges those who draw the map to an intellectual effort aimed at integrating and selecting the data and information to be represented, even from a graphic point of view, due to the limited physical space of the support.

By analyzing Community maps on paper support this intellectual effort in their final graphic representation is clear. On the other hand, the three Community maps developed on a digital support are more dynamic and flexible with regard to data collecting.

They also offer greater possibilities for implementation and updating. Some of the digital Community maps (EUMM and MUMI) offer the public the opportunity to interact and participate in the continuous implementation of the map directly from the ecomuseums websites, sending their own testimonies or suggestions.

For example, MUMI's map is characterized with a link which allows the user to send suggestions for its implementation ("Aggiungi una traccia", e.g. "Add your topic", Figure 1). A similar consideration can be made for the EUMM's map, which is realized on a geo-blogging platform (Salerno et al., 2015).

From the data collection point of view the digital Community maps can be the answer to the limits imposed by the static paper support.

Despite these greater possibilities relating to data collecting, the methods of representation are much more limited compared to maps on paper support (Figure 2). This limitation is only partly compensated by the use of placeholders differentiated by shape and color, to geo-reference different kinds of tangible or intangible landscape components.

The landscape maps produced by PaRID present some common features with the Community maps of the ecomuseums, in particular as regards the purposes and the aspects related to the graphic representation.

Instead, the development process is different. The following paragraphs describe some maps produced by PaRID and will compare them with community maps in a critical manner, highlighting their strengths and weaknesses.
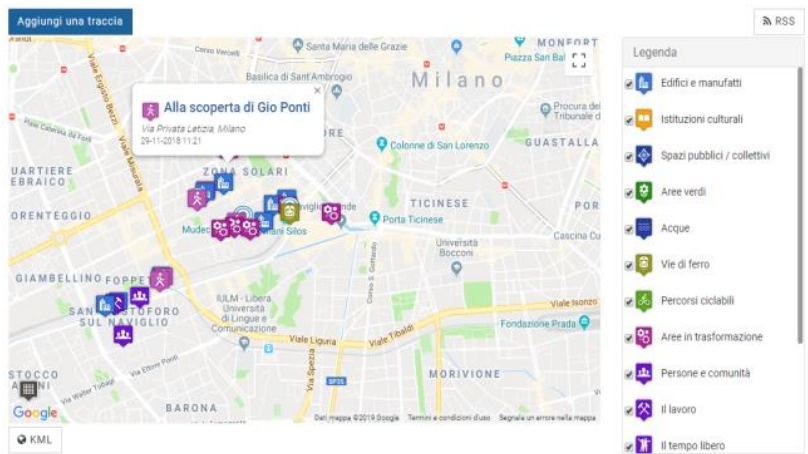

Figure 1. MUMI ecomuseum map (source: https://www.mumiecomuseo.it/infodiscs/index/4, (OMUMI Ecomuseo Milano Sud)

\footnotetext{
${ }^{5}$ www.eumm-nord.it/site/il-geoblog-mappami.html

${ }^{6}$ www.mumi-ecomuseo.it/infodiscs/index/4
}

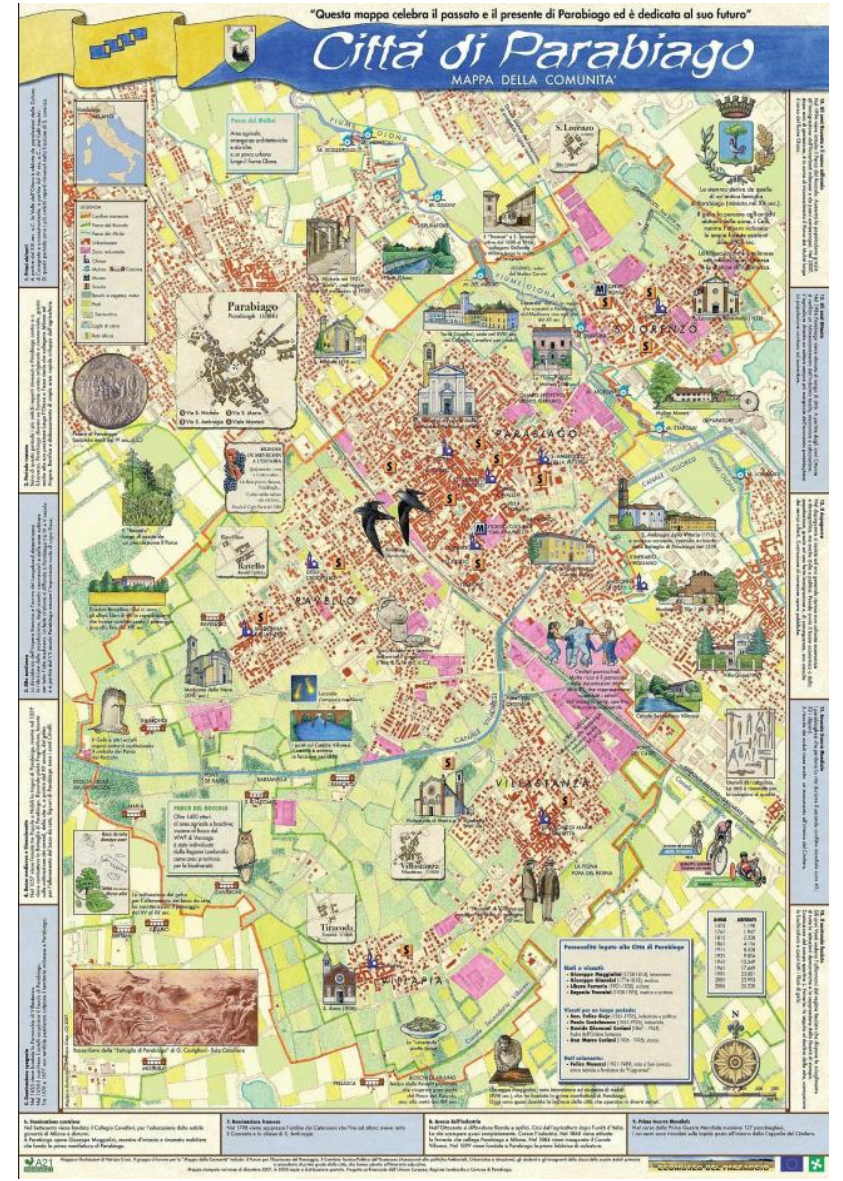

Figure 2. Example of a Community map on paper support (Parabiago ecomuseum, Lombardy (source: ecomuseo.comune.parabiago.mi.it)

\section{MUSA. CYCLING ITINERARIES OF AGRO- CULTURE}

In 2015 the MUSA - Museo Salterio, Officina del Gusto e del Paesaggio (literally: Salterio Museum, Taste and Landscape Workshop) was opened in the refurbished former stall building of the noble ancient Salterio farmstead (Moirago, Zibido San Giacomo) within the Agricultural Park of Southern Milan (PASM). MUSA is a no profit public cultural institution. Through the specific experience of taste in the landscape context it promotes knowledge on the memories and history of place and people. Some of its tools include research and documentation activities on the landscape, training and education in food, activities for different educational stages, a botanical garden, a themed library, a cooking workshop, a permanent multimedia exhibition on landscape. The goals of MUSA are summarized in its statute with five keywords: knowing, discovering, experiencing/experimenting, playing, tasting (Comune di Zibido San Giacomo, 2015).

One major challenge that MUSA faces is to encourage the direct experience of the landscape in its surroundings, without confining landscape to the representations and interpretations that are offered within the building walls. It was decided early on that MUSA would offer bikes for the general public to explore the agricultural countryside, and a small publication in form of a map should aid this exploration. The intention was to build a number of itineraries starting from MUSA and dealing with the cultural value of agricultural heritage. Recipients of the map are the general public that visits MUSA or takes part to its workshops. It is directed to the local layman as well as the 
visiting tourist and should be understandable to different age groups. It must provide information both for the "landscape insider" (as defined by Cosgrove, 1984) to gain a deeper knowledge and connection to the place they have been living and experiencing, and to the "landscape outsider" to get to know it for the first time and have an insight of its character and complexity. It was therefore chosen to use a traditional paper map, with a format usually adopted for trekking or cycling cartography. This traditional format was deemed suitable for outdoors activity and use across different age groups, as well as being less cost-intensive.

Being not only a map about the landscape, but a practical orientation tool for visitors, it had to include different levels of representation and communication. The recto hosts traditional cartography, which most people are acquainted with can read (Figure 3).

The elements included are road networks and waterways, as well as buildings; these are complemented with a mapping of specific elements of land use and vegetation that hint at the overall environmental characters of the landscape, as well as its spatial structure: one can thus identify different agricultural uses (rice paddies, cereal crops, the typical winter-meadows called "marcite"), natural reservoirs, forested areas. Furthermore, being the agricultural landscape prominent, single built artifacts are pointed out: agricultural buildings such as historic farmsteads or mills, symbolic and religious buildings, as well as man-made linear elements like tree rows and the network of irrigation channels and springs ("fontanili"), originating from resurfacing ground waters. Since "taste" is a primary component of the MUSA experience, places where to eat or to buy food directly from the producer are listed. This map does not provide any form of interpretation. It is rather a schematic and selective representation of the physical territory, some of its features and services. It aids navigation, while informing the visitor on some of the general features of the landscape that surrounds them. Information that are specific to cycling and free time activities are included, for instance the presence of cycling lanes, sport facilities or places and buildings of cultural interest. Already traced cycling routes as well as suggested itineraries are marked.

To achieve this selection, after identifying the components to be shown, and bearing in mind the need for a future update of the information, a GIS system was adopted, collecting data sets and layers from a variety of regional and municipal institutional sources. The advanced editing needed to isolate specific elements from the available data required the collaboration of a GIS specialist.

The verso of the map is dedicated to landscape interpretation along one marked itinerary (Figure 4). The itinerary was identified with the principle of connecting landmarks that are representative of the key themes that lend the local landscape its unique identity.

The goal of the verso is to bridge the gap between a static cartographic representation, which offers an external, classificatory and objective point of view, and the direct experience of the landscape from the inside, informed by a selection and interpretation of the historical features that survive in the landscape and their historical relations and dynamics over time $^{7}$.

The key themes that were identified are:

1. the organization of agricultural work along the centuries;

2. water infrastructure at different scales: the ancient irrigation network and the great engineering works, as well as the internal functioning of the winter-meadows;

\footnotetext{
${ }^{7}$ On these two levels of representation see the chapter "Lo sguardo dell'aquila e l'occhio del satellite" in Turri, 2004
}

3. the evolution of land use and crop typologies over time;

4. the traditional rice cropping system;

5. the historical relation between agricultural territories and the city of Milan;

6. the typology, architecture and social organization of the historical farmsteads;

7. the farmstead and its fields as the basic unity of a landscape system;

8. innovative contemporary practices for the compatibility of agriculture and historical rural heritage conservation.

The variety of topics is covered by the ongoing research on agricultural landscape at PaRID; specific research was carried out by a group of historians working on the specific heritage of the area ("Officina dello Storico").

The central picture appearing in the map represents the main route starting from MUSA, running through a series of locations that are named and numbered.

It was a specific choice to not use the range of symbols that are generally adopted to represent landscape interpretation in the process of landscape mapping for study purposes, in order not to confuse the end users with conventions and a graphic language they may mostly not be familiar with.

Instead, part of the fields immediately surrounding each farmstead are represented in vivid but realistic colors, highlighting not only changes in parcel structure and crop variety, but other details too small to appear in the recto, such as the single internal channel structure of each water-meadow. The extension of the drawing is limited to visual barriers, mostly tree rows that form enclosures: the fields are only represented if they are actually visible while cycling along the path. An architectural interpretation of the spatial quality of the landscape is implicitly communicated.

Each theme is explained through a concise text, written for the general public but introducing and shortly explaining numerous landscape-specific terms.

Each text is accompanied by carefully selected archival documentation (mostly ancient cadastral maps), historic and contemporary photographs. All text boxes link information on a specific place, building or area of land along the path to a general topic: who uses the map learns to see and read the fundamental landscape traits encountered in the wider area of the PASM.

While the GIS-controlled section could be relatively easily updated to mirror changes in facilities or routes, the verso is a static representation produced with more intensive work on the graphical side; the text could be easily revised, if new information is gathered through research. A possible form of participation is the wider involvement of local farmers in updating the information on the services they provided, listed on the recto, as well as distributing the map, for example through their points of direct sale.

In the two years after its publication, the map proved to be a valuable resource for educational purposes, for example for the use in open air workshops, or as an informational brochure that is not necessarily used on the suggested actual tour of the landscape. Some form of feedback would be needed to assess its reception from the general visiting public, or as an actual landscape exploration tool. 


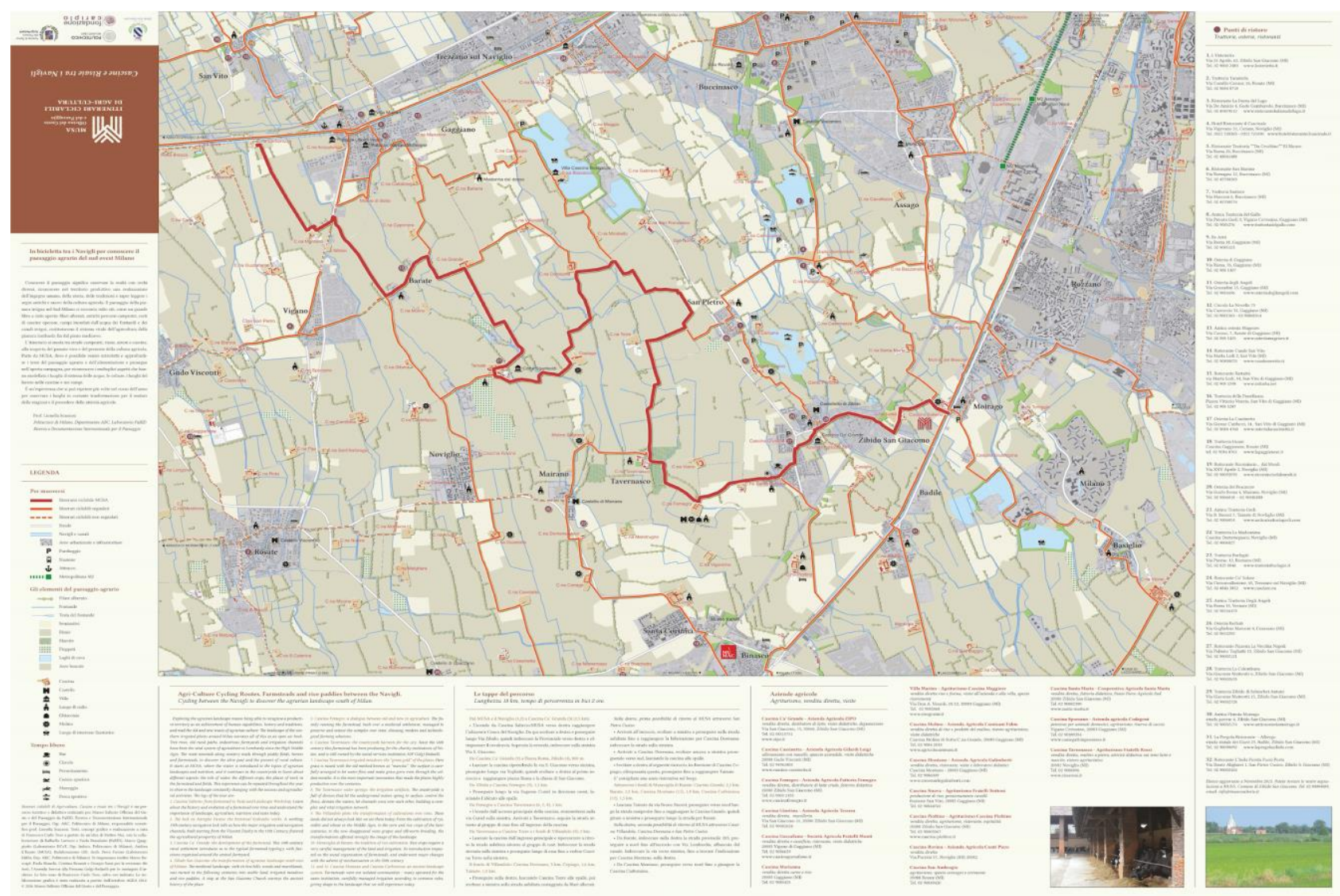

Figure 3. MUSA map (recto)

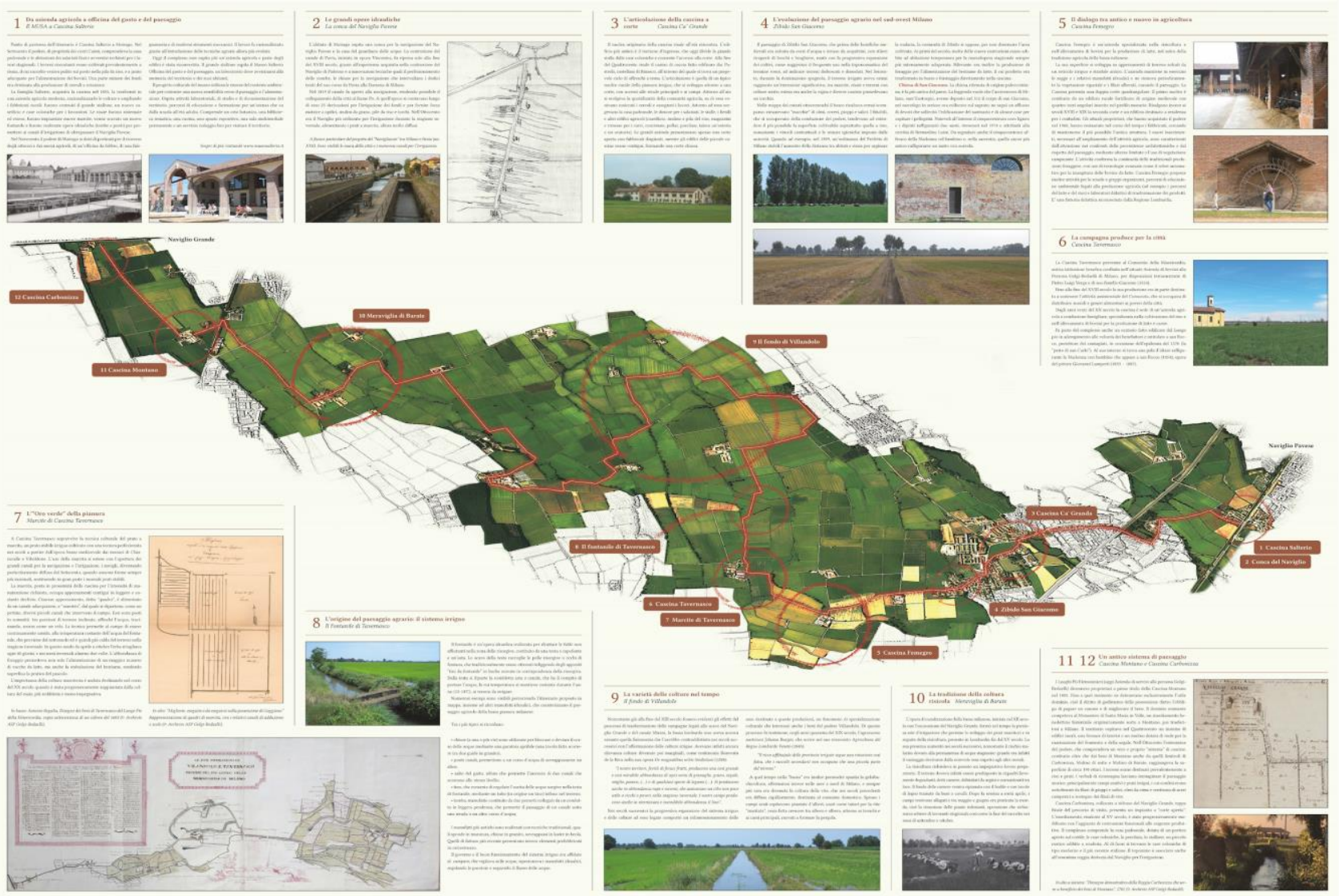

Figure 4. MUSA map (verso) 


\section{4. “THE WAY OF THE WINTER-MEADOWS" MAP}

This map is one of the outputs of "Marcita winter-meadow landscape" project, promoted by Ticino Park with Politecnico di Milano (Dept. ABC, PaRID) and founded by Lombardy Region in 2017, awarded in 2019 with a special mention of the Landscape Prize by the Italian Ministry of Cultural Heritage and Activities (MiBAC).

A multidisciplinary team of experts - agronomists, architects, and ornithologists, with the help of a graphic designer - realized the map. The itinerary leads through the countryside between Robecco, Abbiategrasso and Ozzero Municipalities in the Metropolitan City of Milan, alongside the course of Ticino river.

It runs up and down the river terraces, from North-West to South-East.

The itinerary crosses many water canals in a changing landscape, characterized by permanent meadows, rice fields and other cereals crops, rows of trimmed willows, alders, poplars and thick bushes.

This landscape is rich in farmhouses, which have been custodians and managers of its heritage for centuries, modelled by a plenty of surface and ground water.

The map is composed of two sides:

1. The recto (Figure 5) is a geographical map with the itinerary and main landscape attractions. Key elements are winter-meadows, cereals fields, farmhouses, animals (especially birds), water canals and vegetation (linear and woods). Agritourism facilities and direct sell of agricultural products are also indicated;

2. The verso (Figure 6) is divided into two narrative and two visual parts: a description of the itinerary; a description of the evolution and present values of marcite-meadows landscape; an axonometric bloc-diagram of the landscape system with explanation of landscape elements and their functional and historic relations; four schemes illustrating main water canals and the landscape they crossed.

The graphic design used for the map is based on a technical cartography (CTR, by Lombardy Region), elaborated with Photoshop software in order to achieve a more charming graphic result than in a technical map; a similar graphic design is it used for the landscape diagram. The aim was to reach a large number of people from children to adults, attracting them thanks to a "friendly" graphic result.

In a first stage, icons have been designed for all the landscape components (humans, animals, as well as farmsteads) with a realistic graphic representation and not with to a symbolic design.

Subsequently the Authors opted for a symbolic representation of the most important landscape components, that can be easily repeated in the map.

This kind of elaboration does not allow an easy updating, because it has been not designed and developed with a GIS system: this means that the map would have to be re-edited in case of modifications or additions.

In the recto, contents have been selected in order to illustrate tangible and intangible components in the current landscape and their main relationships to agricultural activity: tangible landscape components described are canals, vegetation, rural buildings; the intangible ones are the technics carried out by farmers (vegetable gardening and drowning of rice fields or winter-meadows).

The presence of animals on the map, especially birds, makes the landscape alive.

In the verso, the bloc-diagram describes graphically the landscape components and the relationships among them in the present as in the past: changes in habits, agricultural land-uses and technics are described in order to illustrate the landscape system evolution. Moreover, the four canals diagrams exemplify the importance of water connections in a landscape made on and by water: they describe what landscape the canals cross, what elements touch, which fields feed with water. It is an opportunity to have a suggestion of the visual perception offered by the itinerary.

Map and graphic elaborations are the results of an interdisciplinary and expert work: a check of agricultural fields and farmhouses has been done by selected farmers, before the final editing phase. Nevertheless, the map itself is the output of long-lasting process (more than 30 years) of sharing and exchanging among the Ticino Park technicians and farmers: the map becomes a chance for the farmers to visualize and register their landscape as heritage and sharing it with the local community.

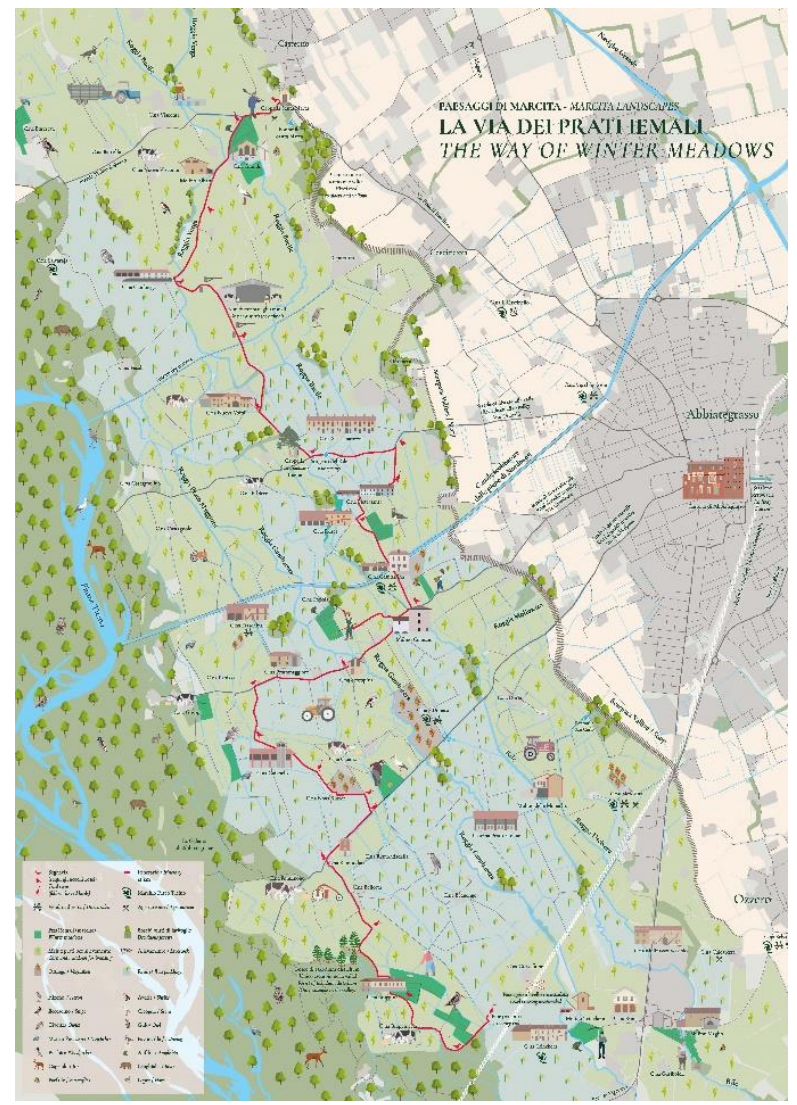

Figure 5. Winter meadows map (recto) 


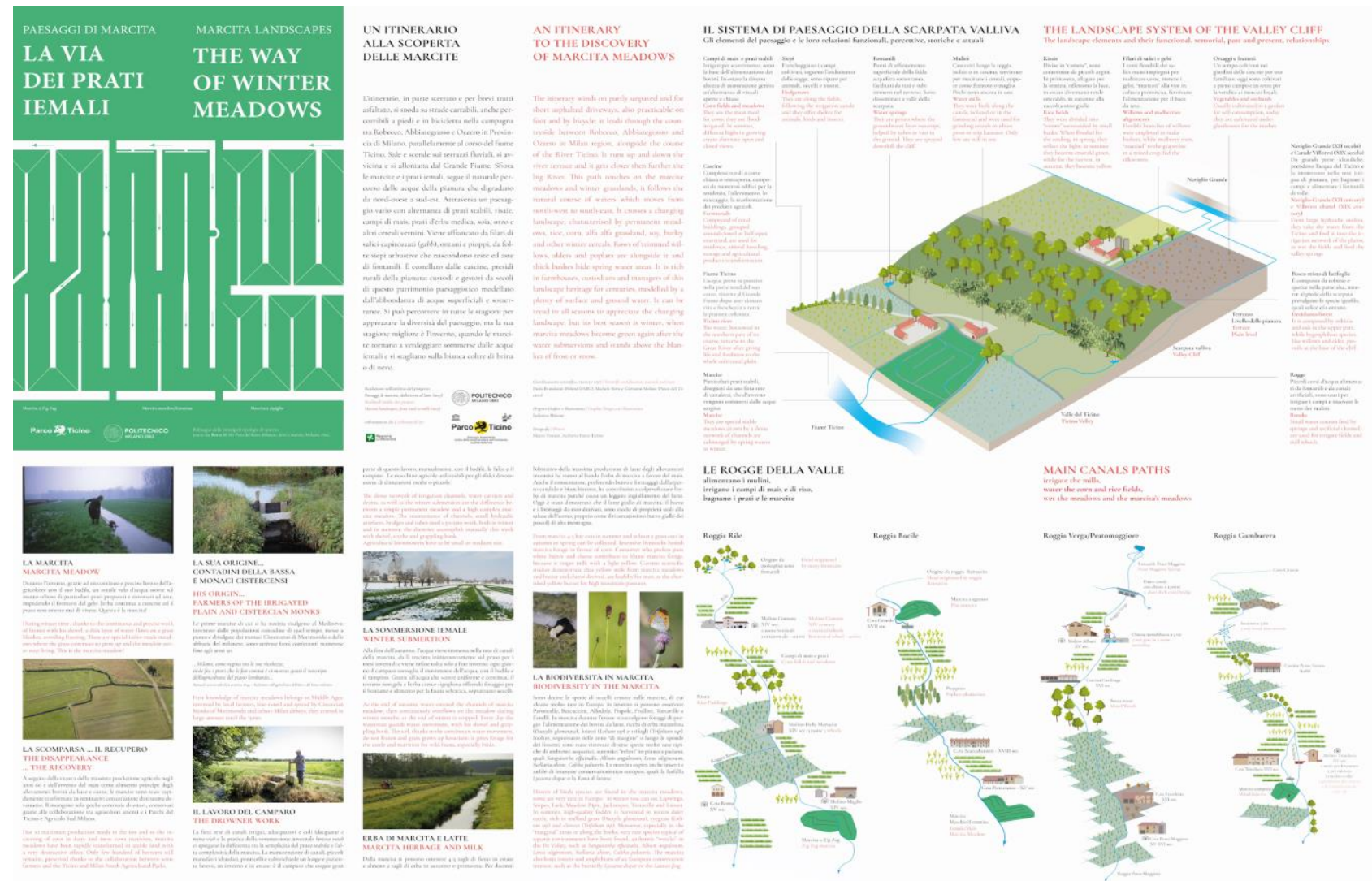

Figura 6. Winter meadows map (verso)

\section{CONCLUSIONS}

The main difference between the Community maps issued by ecomuseums and the itinerary maps developed by PaRID lies in the adopted approach.

Community maps follow a bottom-up approach, where contents are suggested directly by people. This allows to broaden knowledge on places and landscapes and discover yet unexpressed perceptions. In these cases, the role of the experts is to welcome and correctly address new content, more than proposing new interpretations or content. For this reason, there is the risk that values that are not recognized by the wider public remain unrepresented.

PaRID developed its maps following an informed, specialist top-down approach, where experts in the field select the data and information to be represented, the result of an in-depth research of bibliographic sources and archival historical documents. In a second step, through the involvement of selected interlocutors (mainly the interested institutions or farmers), the map is completed with knowledge and perceptions brought by local people.

This reflects in the selection of content. Tangible monumental heritage and tangible heritage which is often considered minor, are both featured in both examples. On the contrary, intangible heritage is taken into consideration more by Community maps than by PaRID itinerary maps.

The graphical representation of a landscape system results clearer in the itinerary maps, where textual descriptions and images complement each other. The common purpose is to represent the same complex data with enough clarity and simplicity. However, the graphical representation methods can vary significantly. Community maps often show the informal graphical language most commonly used in common tourist maps. This causes a homogenisation and in several cases the specific character of the landscape does not clearly emerge.
In the case of itinerary maps, the graphical representation combines different tools (cartography, photographic images, historical documents), thus unfolding different levels of depth and perception. In fact, it maintains a link with territorial technical cartography, but tries to go beyond its fixity and rigour. The use of the simple and colorful design created ad hoc allows for a more inclusive communication to different user types.

Nevertheless, these are printed static maps and therefore present some critical issues: the difficulty of updating, if not by a work revision; the lack of interaction, when the map is formalized; a rather limited diffusion.

The involvement of the population appears to be a useful tool for the construction of a landscape map and the implementation of intangible heritage content. The dialogue between experts and the population is a fundamental tool for the exchange of knowledge and perceptions of the analyzed landscape. It stimulates the recognition of the landscape as a heritage and helps unravelling its complexity.

Sometimes the work of experts is thwarted by the inability to find adequate distribution tools, a problem which can be overcome through the direct involvement of the population in disseminating the results. The dissemination and sharing of knowledge are certainly essential factors also for the activation of bottom-up heritage protection initiatives.

The broader participation of citizens must not be a reason for renouncing a representation that, while aiming to be as widely understandable as possible, is at the same time specific. In this sense, the limitations of paper support can be overcome by adopting digital media, allowing for a more rapid and constant implementation of the data as well as a continuous interaction between those involved in the construction of the map. The creation of web platforms makes it possible to broaden the range of data collected: personal memories, minute traditions, historical photographs. 
This was experimented with the website www.campocascina.polimi.it ("Cura del paesaggio, Salute delle persone. Viaggio nel tempo nella campagna che nutriva I malati della città di Milano"), a project carried out by PaRID lab with the Cà Granda Foundation and funded by the regional Administration of Lombardy: around ten historical maps, representing the Morimondo area circa 1775, coming from the historical archive of the Ospedale Maggiore in Milan, has been geo-referenced on the Google cartography. A proposed itinerary of discovery of the landscape heritage allows to switch with a single click over two centuries and let immerse users in the reality of the 18th century, in a sort of travel through time and space. Historical maps detail landscape elements, toponyms and crops, while being aesthetically beautiful and colourful. They are combined with georeferenced historical photos and descriptions of agricultural buildings and landscape from historical agricultural contracts. Through the immediate comparison between past and present, the reading of permanencies in today's landscape is more effective and allows to reach both an expert user (officials of the bodies that evaluate landscape transformations) and a large audience discovering the beauty of these historical documents.

Integration with local memory, recollections and traditions would be desirable, to constantly nurture the link between past and present. This way, local involvement would increase the intangible register of the landscape, which is still lacking today: the experts would play a role both as integrators and mediators of landscape culture.

Finally, digital maps that collect and georeference data can help illustrate and understand both tangible and intangible characters of landscape dynamically, illustrating better the complexity of landscape systems; they are potential tools to overcome the gap between the shared bottom-up approach and the specialist topdown approach.

\section{REFERENCES}

Antrop, M., 2005. Why landscapes of the past are important for the future. Landscape and Urban Planning, 70, 21-34

Antrop, M., 2012. Intrinsic values of landscapes. In T. Papayannis, \& P. Howard (eds.), Reclaiming the Greek Landscape (pp. 31-42), Athens: Me-INA

Baratti, F., 2017. Ecomuseums and social production of landscape in Apulia. In R. Riva (ed.), Ecomuseums and cultural landscapes. State of the art and future prospects (pp. 238-246). Santarcangelo di Romagna: Maggioli Editore.

Berque, A., 1995. Les raisons du paysage, De la Chine antique aux environnements de synthèse, Paris: Hazan

Branduini, P., Laviscio, R., \& Colombo, C.F., \& 2017. Landscape maps: knowledge and management tools for Cultural Heritage. In R. Riva (ed.), Ecomuseums and cultural landscapes. State of the art and future prospects (pp. 252-260). Santarcangelo di Romagna: Maggioli Editore

Clifford, S., \& King, A., 1996. From Place to PLACE: maps and Parish Maps. London: Common Ground

Comune di Zibido San Giacomo, 2015. La carta dei Servizi del Museo Salterio. $\quad$ Retrieved from: http://www.museosalterio.it/wordpress/wpcontent/uploads/2015/10/Carta-dei-Servizi-MUSA-NUOVAVERSIONE.pdf [accessed 11 March 2019]
Cosgrove, D.E., 1984. Social formation and symbolic landscape. London: Croom Helm

Council of Europe, 2000. European Landscape Convention. Florence 20 October 2000. Retrieved from: http://rm.coe.int/1680080621 [accessed 10 March 2019]

D’Amia, G. (2017). Gli ecomusei in Italia: una realtà in evoluzione. Territorio, 82/2017, 87-103. Milano: Franco Angeli

Drugman, F.; Brenna, M. (ed.), 2010. Lo specchio dei desideri: antologia del museo. Bologna: Cluep. (Originally published in 1989)

Langè, S., Rabino, G., Bossi, P., \& Laviscio, R., 2008. Attese, intenzioni e progetti delle comunità locali nella costruzione dell'immagine del territorio. Fattori e dinamiche nel tempo. In P. Bossi, S. Moroni, \& M. Poli (eds.), La città e il tempo: interpretazione e azione. Santarcangelo di Romagna: Maggioli Editore

Laviscio, R., 2008. Le relazioni tra bene paesistico e contesto. In S. Langè (ed.), Chora. Il paesaggio riconosciuto, Milano: Franco Angeli Editore

L'Erario, A., 2017. Ecomusei: un itinerario attraverso le regioni italiane. Territorio, 82/2017, 104-113. Milano: Franco Angeli

Luginbühl, Y., 2012. La mise en scène du monde, Construction du paysage européen. Paris: Éditions du CRNS

Madau, C., 2015. "Le mappe di comunità": esperienze di cartografia partecipata per lo sviluppo locale. In ASITA 2015, Proceedings of ASITA Conference (Federazione italiana delle Associazioni Scientifiche per le Informazioni Territoriali e Ambientali) (pp. 541-548), 29 September-1 October 2015, Lecco, Politecnico di Milano

Maggi, M., 2002. Ecomusei. Guida Europea. Torino: Umberto Allemandi

Riva, R., 2008. Il metaprogetto dell'ecomuseo. Santarcangelo di Romagna: Maggioli Editore

Salerno, R., Casonato, C., Villa, D., 2015. Sharing heritage: the urban ecomuseum in Milan experiences of participation and new information technologies. Paper presented at the 9th International Forum "Le Vie dei Mercanti", 9th-11th June 2011, Aversa, Italy

Scazzosi, L., 2018. Landscape as system of tangible and intangible relationships. Small theoretical and methodological introduction to read and evaluate Rural Landscape as Heritage. In E. Rosina \& L. Scazzosi (eds.), The conservation and enhancement of built and landscape heritage (pp. 19-40). Milan, Italy: PoliScript, Politecnico di Milano

Turchi, A., 2015. Dalle Parish Maps britanniche alle Mappe di Comunità italiane. Retrieved from: https://issuu.com/agneseturchi/docs/parish_maps_mappe_di_co munit__ [accessed 10 March 2019]

Turri, E., 1998. Il paesaggio come teatro: dal territorio vissuto al territorio rappresentato. Venezia: Marsilio

Turri, E., 2004. Il paesaggio e il silenzio. Venezia: Marsilio 